\title{
Modeling Integrated Coastal Flood Hazard in Hurricane Season
}

\author{
Liber Galbán Rodríguez¹, Lázaro Rodríguez Tamayo², Fernando Durán Rodríguez¹, \\ Alexis Santiago Perez Figueredo ${ }^{3}$
}

\footnotetext{
${ }^{1}$ School of Construction, Department of Hydraulic Engineering, Universidad de Oriente, Santiago de Cuba, Cuba ${ }^{2}$ Department of Topography, José Maceo Grajales Higher Institute, Santiago de Cuba, Cuba ${ }^{3}$ School of Construction, Multidisciplinary Coastal Zones Study Centre, Universidad de Oriente, Santiago de Cuba, Cuba Email: liberg@uo.edu.cu, lazarorodrigueztamayo@gmail.com, fernando.duran@uo.edu.cu, alexis.figueredo@uo.edu.cu
}

How to cite this paper: Rodríguez, L. G., Tamayo, L. R., Rodríguez, F. D., \& Figueredo, A. S. P. (2021). Modeling Integrated Coastal Flood Hazard in Hurricane Season. Journal of Geoscience and Environment Protection, 9, 161-179.

https://doi.org/10.4236/gep.2021.910012

Received: September 17, 2021

Accepted: October 26, 2021

Published: October 29, 2021

Copyright $\odot 2021$ by author(s) and Scientific Research Publishing Inc. This work is licensed under the Creative Commons Attribution International License (CC BY 4.0).

http://creativecommons.org/licenses/by/4.0/

\begin{abstract}
The manuscript proposed a procedure designed to determine the hazard of total coastal flooding during the impact of hurricanes, which uses in its formulation the combination of river flooding and that caused by marine upwelling, which is multiplied by a density factor of the water that finds an explanation for the effect is shielding and rising of the water level when the currents of both floods collide in the coastal zone. The application of the procedure experimentally in the coastal sector Sevilla, of the municipality Guama province Santiago de Cuba, resulting in the confirmation of areas previously modeled and estimated coastal flooding in the wake of extreme weather events in the study area; in addition to other new areas that confirm the actual visual and instrumental observations not included in previous studies.
\end{abstract}

\section{Keywords}

Coastal Flood, Hurricane, Modeling, Density Factor, GIS, Santiago De Cuba

\section{Introduction}

Coastal flooding is a global hazard. A large and growing fraction of the world's population is living on the coasts, and a significant part of it is vulnerable to coastal flooding in the developed and developing world. It has been calculated that in the 20th century 3.2 million people have died for this reason, which is more than half of the deaths from natural disasters in the world in that period (Lara, 2012) as explained in Figure 1 and Figure 2.

According to studies carried out by Tellman et al. (2021), the worst is yet to come, since it is estimated that by 2030 new 25 countries will be added to the 
risk of flooding to the 32 that are already experiencing its effect so far in the 21st century, due to climate and demographic change. By then, more than 179 million people will be added to these flood-prone regions, especially in Asia and Africa. In recent years, almost $90 \%$ of the floods occurred in South and Southeast Asia, affecting a greater number of people in the large basins (Indo, GangesBrahmaputra and Mekong), most of them located in Coastal areas exposed to cyclones or hurricanes and tropical storms, areas where river floods converge with floods generated by the marine upwelling known as flood by penetration of the sea.

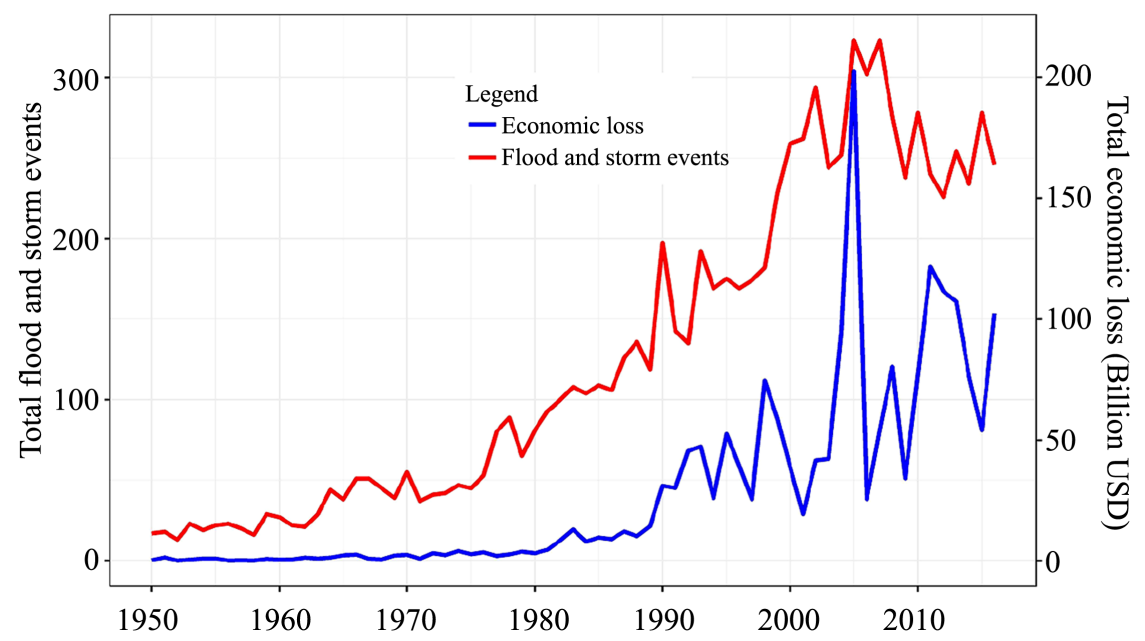

Figure 1. Global flood and storm events vs. economic loss between 1950 and 2016 (Luu et al., 2017).

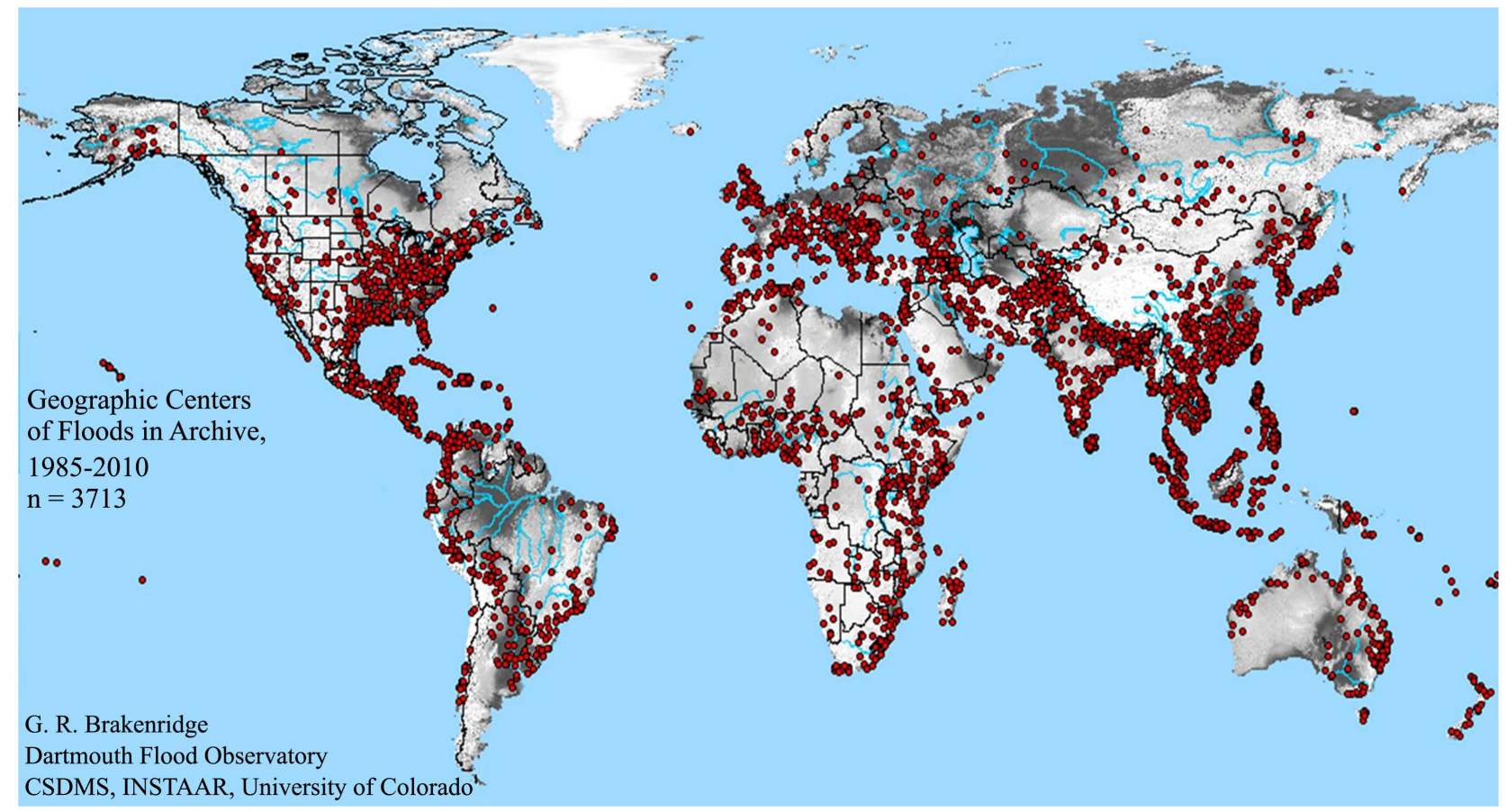

Figure 2. Geographic centers of floods in the flood archive GIS file, 1985-2010 (Brakenridge, 2016). 
In this context, the international scientific literature recognizes only the following types of coastal flooding (Rodriguez, 2020):

- Flooding caused by tsunamis or tidal waves. The seismic and volcanic activity, which generates the so-called tsunamis or tidal waves, forming giant waves several meters high that suddenly flood the coasts.

- Flood caused by the astronomical tide.

- Flooding caused by the storm surge (marine upwelling effect), also known as flooding due to penetration of the sea.

The action of winds from tropical storms, hurricanes, typhoons or tropical cyclones and intense low pressures systems close to the coast, can lead water from the ocean to inland and cause coastal flooding due to penetration of the sea. The marine upwelling effect is nothing more than the abnormal and temporary rise in sea level, on the predicted astronomical tide, caused by the tension produced by strong winds and, to a lesser degree, by the drop in atmospheric pressure, due to the passage of one of the aforementioned atmospheric phenomena; which causes seawater to penetrate inland, affecting emerged areas and devastating everything in its path (Figure 3 ).

Particularly hurricanes, tropical cyclones or typhoons, bring with them intense rains and strong winds that often cause flooding, both inland due to the intense accompanying rains (river floods), as well as due to the action of the winds and the rising of the sea and the waves on the coasts.

For studies of hazard, vulnerability and risk of coastal flooding by heavy rains and penetration of the sea developed by several institutions and specialists internationally, the trend is to design spatially modelling of their behavior separately and then join them or superposition of them to determine a unique area of flooding in the coastal area. It should be noted that, despite constituting an initial proposal for disaster reduction plans of hydro meteorological origin for a territory, these approaches contain shortcomings for their correct implementation by decision-makers, the main one is related to:

- Coastal flooding caused by the simultaneous combination of heavy rains and sea penetrations due to upwelling, during the occurrence of extreme hydrometeorological phenomena, is not comprehensively evaluated.

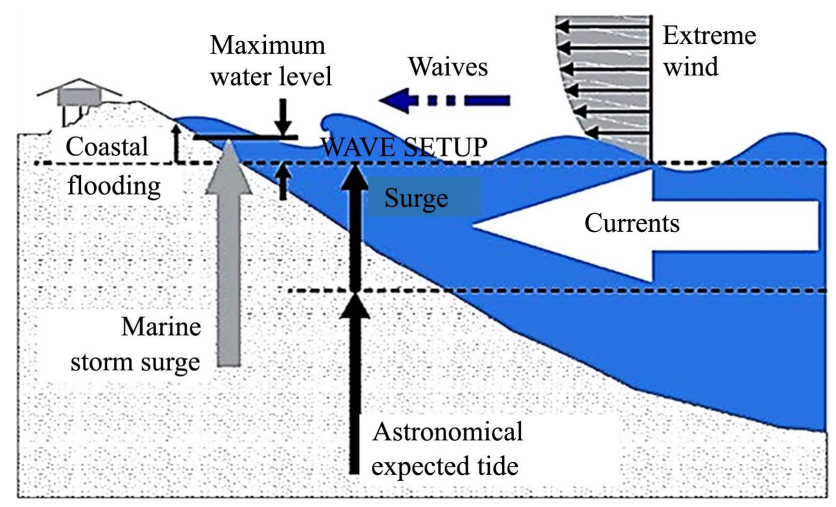

Figure 3. Components of the storm tide (AMA, 2014). 
Under these conditions, it is necessary to understand that the river flooding and the one that originates the marine upwelling, often are combined in the coastal zone, growing in height inland as a result of the difference in density between fresh water and salt water, as well as by the speeds that the currents bring themselves. This phenomenon of combined flooding in coastal areas has been widely observed internationally, we need only cite, for example, the passage of Hurricane Sandy in February of 2012 by eastern Cuba and Hurricane Katrina in 2005 by the South the United States. In the case of Cuba, the passage of Sandy to the west of the Santiago de Cuba province in the Guamá municipality, caused floods that exceeded in several points of the coastal geography the maximum values estimated in the studies previously carried out by national specialists (Galbán, 2014).

In the United States Hurricane Katrina, is recognized as one of the most expensive, deadliest and destructive tropical cyclones has impacted this country in decades, ravaging the coast of the Gulf of Mexico and taking in New Orleans the largest number of deaths of the area. It caused 2541 deaths and an economic cost in losses of $\$ 89,600$ million USD (the largest recorded by a hurricane in history to date). It became the most disastrous hurricane after Hurricane Okeechobee in 1928 (Blake et al., 2011) (Figure 4).

For the reasons previously mentioned, in this paper was proposed as general objective: modeling and determination of coastal flooding total hazard caused by the simultaneous combination of heavy rains and the penetration of the sea due

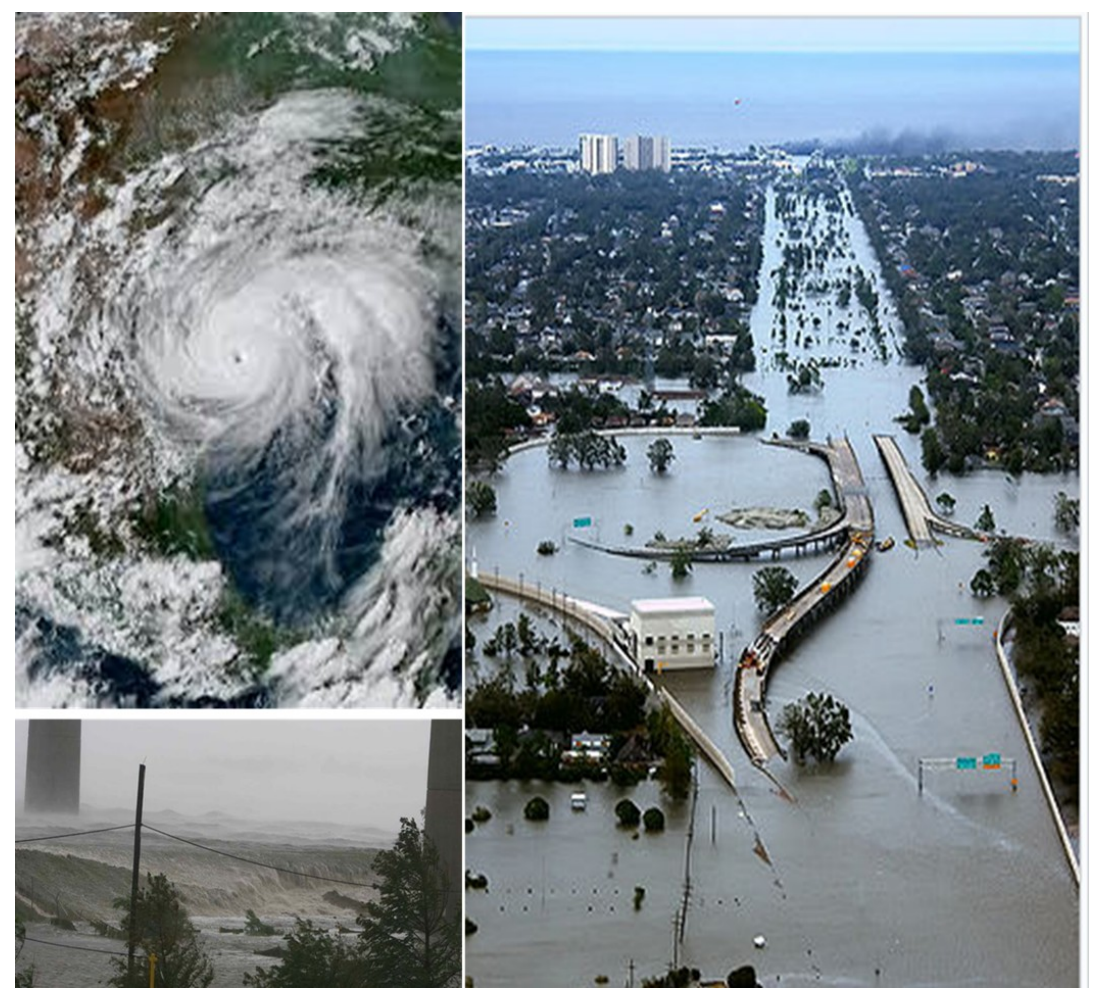

Figure 4. Collage of images taken from the web, showing the damage caused by flooding following Hurricane Katrina in the coastal city of New Orleans, United States. 
to the upwelling during the occurrence of extreme hydrometeorological phenomena (tropical storms and hurricanes), using Geographic Information Systems (GIS). A locality in the Guamá municipality of the Santiago de Cuba province is chosen for the application of a methodology proposed by the authors for the occasion.

\section{Materials and Methods}

The methodology used in this work requires the combined use of a cartographic base developed and supported on a GIS. In order to obtain the necessary information, a large database must be had, in addition to the necessary bibliographic search from various sources (scientific articles, reports, theses, books, and specialized websites, among others). On the other hand, visits to the location or study area are usually necessary; this is the only way that the research team take relationship directly with the investigated situation, allowing also rectified directly on the ground the details that do not appear on maps and previous studies by the method of direct mapping. The data are incorporated into the GIS delimiting maps or models to geographically coincidences in order to avoid differences, thus guaranteeing a good cartographic precision and the same spatial resolution.

The proposed methodology for evaluating the risk of total coastal flooding hazard in the hurricane season includes the following mathematical formulation:

$$
\mathrm{Pt}_{\mathrm{ic}}=\left[\mathrm{P}_{11}(\text { Weight })+\mathrm{P}_{\mathrm{ipm}}(\text { Weight })\right] * \text { Fda }
$$

where:

- $\mathrm{Pt}_{\mathrm{ic}}$ : Total Coastal Flood Hazard Model.

- $\mathrm{P}_{11}$ : Primary model of floods due to heavy rains.

- $\mathrm{P}_{\mathrm{ipm}}$ : Primary model of floods due to penetration of the sea.

- Fda: The ratio between density of sea water and fresh or drinking water.

- Weight: assigned weight to the indicator or factor in the formulation whose value is $0-1$ (the sum of the weights must be equal to 1 ).

The model is a shot of a moment that, as any other model obtained with a GIS needs to be actualized from time to time. The variable used on them most have the intrinsic values of the location in which it is applied, differing from location to other. In the case of the weights, as said in the formulation, the sum of them must be equal to 1 and depends on the case of tropical hidro meteorological phenomena in analysis as is exposed farther more in Table 1.

The penetration of the sea during tropical cyclones collides with the flooding caused by the avenues of the rivers, then a shielding occurs due to the difference in densities, forcing the runoff to recede, originating the increase in the flood level where the maximum flood condition take place. It is for this reason that the density factor of the water on the coasts Fda is introduced, whose formulation and final value are expressed below:

$$
\text { Fda }=\frac{\text { Density of sea water }}{\text { Fresh or drinking water density }}=\frac{1027 \mathrm{~kg} / \mathrm{m}^{3}}{1000 \mathrm{~kg} / \mathrm{m}^{3}}=1.027
$$


Table 1. Levels proposed for the consideration of the weight of the type of flood in the formulation.

\begin{tabular}{ccc}
\hline Category & $\begin{array}{c}\text { Weight of the flooding } \\
\text { due to marine upwelling }\end{array}$ & $\begin{array}{c}\text { Weight of flooding } \\
\text { due to rains }\end{array}$ \\
\hline Tropical Wave & $\leq 0.25$ & $\geq 0.76$ \\
Disturbance & $\leq 0.25$ & $\geq 0.76$ \\
Depression & $\leq 0.25$ & $\geq 0.76$ \\
Tropical storm & $\leq 0.25$ & $\geq 0.76$ \\
Category 1 & $\leq 0.25$ & $\geq 0.76$ \\
Category 2 & From 2 $6-0.50$ & From $0.51-0.75$ \\
Category 3 & 0.50 & 0.50 \\
Category 4 & From $0.51-0.75$ & From $26-0.50$ \\
Category 5 & $\geq 0.76$ & $\leq 0.25$ \\
\hline
\end{tabular}

Can also be calculated in this case the density of the sea water and river water under the conditions of atmospheric pressure that predominates in the geographical area subject to analysis, or particular climatic conditions, such as variations of atmospheric pressure for tropical cyclones. In this investigation, the value of the densities under normal atmospheric pressure conditions is taken as a starting point.

The coastline is also taken as the geographical place where the two types of floods coincide, and the closing limit for the inland calculation of the heights and total flood levels.

To achieve the same information scale, all the assigned indicators and weights were standardized and considered between the values of 0 and 1 , considering them in 4 levels as proposed (Galbán, 2014) (Table 2). In this way, a submodel was obtained for each indicator.

To classify tropical cyclones, the Saffir-Simpson scale is used, which is the most reliable method known to recognize the intensity that hurricanes are going to have (Table 3) and is used, mainly in the American continent, for hurricanes that exceed the intensities of tropical storms and depressions. This hurricane scale is divided into five categories that indicates the damage that the worst hurricanes can cause based on the speed of the winds and the atmospheric pressure. Category 1 is the mildest and Category 5 the most destructive of this hurricane scale (Table 3 ).

The current speed factor is not introduced directly taking into account the weight of rainfall and marine upwelling in hurricanes, which includes the incidence of wind speeds and flows according to the categories of hurricanes (Table 1).

The hazard of flooding due to intense rains $\left(\mathrm{P}_{11}\right)$ combines the susceptibility indicators of the hazard scenario or areas susceptible to flooding (Ia) and the trigger factor $(\mathrm{Fd})$, which are the intense rains and is expressed as follows: 
Table 2. Classification and values for standardization of HVR (Galbán, 2014).

\begin{tabular}{ccccc}
\hline & First level & Second level & Third level & Fourth level \\
\hline \multirow{2}{*}{ HAZARD } & NONE - LOW & MODERATE & HIGH & VERY HIGH \\
& $(0-0.25)$ & $(0.26-0.5)$ & $(0.51-0.75)$ & $(0.76-1)$ \\
\hline
\end{tabular}

Table 3. Classification of tropical cyclones according to NOAA.

\begin{tabular}{ccccc}
\hline Category & Pressure $(\mathrm{mb})$ & Winds $(\mathrm{km} / \mathrm{h})$ & Storm Surge $(\mathrm{m})$ & Wind effect damage \\
\hline Tropical Wave & - & - & - & Minimum \\
Disturbance & 1008 & - & - & Minimum \\
Depression & 1005 & 62 & - & Minimum \\
Tropical storm & $985-1004$ & $63-117$ & 1.1 & Minimum \\
& Hurricane, tropical cyclone, typhoon & \\
Category 1 & $>980$ & $119-153$ & 1.5 & Minimum \\
Category 2 & $979-965$ & $154-177$ & $2.0-2.5$ & Moderate \\
Category 3 & $945-964$ & $178-209$ & $2.5-4.0$ & Extensive \\
Category 4 & $920-944$ & $210-249$ & $4.0-5.5$ & Extreme \\
Category 5 & $<920$ & $>250$ & $>5.5$ & Extreme \\
\hline
\end{tabular}

$$
\mathrm{P}_{\mathrm{ll}}=\sum_{n=1}^{\infty} \mathrm{Ia} \text { (weight) } * \text { Fdi }(\text { weight })
$$

where:

- $\mathrm{P}_{11}$-Primary model of floods due to heavy rains.

- Ia-indicators of susceptibility of the land or flood scenario.

- Fdi-Trigger factor (maximum average rainfall recorded in the study area).

- $n$-Number of indicators,

- Weight-weight assigned to trigger factor and land scenario in correspondence of kind of hydro meteorological phenomena in analysis as stated above in Table 3. Always goes from $0-1$ (the sum of the weights must be equal to 1).

By breaking down the formula, indicators are understood to be the different layers or cartographic information previously obtained, which towards the interior are also multiplied by weight factors, according to the incidence assessment proposed by the authors; remaining as follows :

$$
\begin{aligned}
\sum \text { Ia }= & \text { submodel Slope }(0.55)+\text { submodel lithological Susceptibility }(0.15) \\
& + \text { submodel karst influence }(0.1)+\text { submodel water tables }(0.1) \\
& + \text { vegetation coverage }(0.1)
\end{aligned}
$$

There are other authors who prefer to work with the Maning coefficient. This is a variant that can also be assumed because it reflects in the same way the susceptibility of the land to be flooded in values similar to those shown in Table 2.

- Slope Submodel: The slope value is a very important indicator. If the area to be studied is around a very steep slope, then it will be obtained that the flow 
of water will run with greater difficulty, it will be more difficult for part of the seawater sheet to infiltrate inland. If, on the other hand, it is located on a surface where the inclination is little, the flow of water that will move over it will make it easier, allowing part of it to infiltrate, letting greater penetration of the sea water. In the case of fluvial floods brought by rivers, the same thing happens, the greater the slope, the less geographic extension, and the less the slope, the greater extension. The following table expresses the authors' criteria, based on national and international experiences (Table 4).

- Submodel lithological Susceptibility: Among the elements of geology to consider to analyze the flood hazard in a given territory, it is the lithology (rock types), and within it, specifically the degree of natural rocks permeability, which is grouped into the different types of rocks in four groups or categories (Table 5).

- Karstic Influence Submodel: Non-karstic reliefs are the most susceptible to flooding, because they are formed by low rocks permeability, the opposite occurs in reliefs with extensive karstic development (Table 6).

Table 4. Tiers for the considerations of the influence of the slope.

\begin{tabular}{ccccc}
\hline \multirow{2}{*}{ Variable } & Low & Moderate & High & Very high \\
\cline { 2 - 5 } & $(0-0.25)$ & $(0.26-0.5)$ & $(0.51-0.75)$ & $(0.76-1)$ \\
\hline Topographic slope in degrees & Greater than 10 & $5-10$ & $5-2$ & $2-0$
\end{tabular}

Table 5. Classification of lithological influence or geological susceptibility, according to the general conditions. Adapted from Galbán et al., 2012.

\begin{tabular}{|c|c|c|c|}
\hline Rock types & General lithology & Susceptibility & Representative groups \\
\hline $\begin{array}{l}\text { Rock of any type, } \\
\text { sedimentary or crystalline } \\
\text { Rigid soils with a thickness } \\
\text { of less than } 60 \mathrm{~m} \text { to the rocky } \\
\text { base, as long as the upper strata } \\
\text { are composed of stable deposits } \\
\text { of sand, gravel or hard clay }\end{array}$ & $\begin{array}{l}\text { Impervious limestones, basalts, } \\
\text { andesites, low degree of weathering, } \\
\text { little fracturing, rocks with high } \\
\text { resistance to shear, low groundwater level. }\end{array}$ & $\begin{array}{l}\text { Very high } \\
(0.76-1)\end{array}$ & $\begin{array}{l}\text { Andesite, diorite, porphyry, granites } \\
\text { Serpentinite, riodacite, rhyolite, } \\
\text { marbles, compact limestones }\end{array}$ \\
\hline $\begin{array}{l}\text { Stable deposits of non-cohesive } \\
\text { soils or hard clays when their depth } \\
\text { to the rocky base exceeds } 60 \mathrm{~m} \\
\text { and the upper strata are composed } \\
\text { of sands, gravels or hard clays }\end{array}$ & $\begin{array}{l}\text { High degree of weathering of the } \\
\text { above mentioned rocks and massive } \\
\text { clastic sedimentary rocks, } \\
\text { low resistance to shear, shear fracture. }\end{array}$ & $\begin{array}{l}\text { high } \\
(0.51-0.75)\end{array}$ & $\begin{array}{c}\text { Permeable limestones, } \\
\text { Schists, clastic metamorphites, } \\
\text { fissured igneous } \\
\text { Gaps and compact conglomerates, } \\
\text { cohesive sandstones }\end{array}$ \\
\hline $\begin{array}{l}\text { Deposits of soft or medium clays } \\
\text { and sands with thicknesses of } \\
10 \mathrm{~m} \text { or more with or without the } \\
\text { presence of intermediate layers of } \\
\text { sand or other non-cohesive soils }\end{array}$ & $\begin{array}{l}\text { Poorly consolidated rocks or soils, } \\
\text { considerable weathering of sedimentary, } \\
\text { intrusive and volcanic rocks, } \\
\text { fluctuations in the water table. }\end{array}$ & $\begin{array}{l}\text { Moderate } \\
(0.26-0.5)\end{array}$ & $\begin{array}{c}\text { Vulcanogenic-sedimentary rocks } \\
\text { Compact clays } \\
\text { Massive clayey rocks with jointing, } \\
\text { jointed conglomerates with medium cohesion }\end{array}$ \\
\hline $\begin{array}{l}\text { Clay and soft sand deposits with } \\
\text { thicknesses greater than } 12 \mathrm{~m}\end{array}$ & $\begin{array}{l}\text { Quaternary unconsolidated soils, } \\
\text { clay fill, unconsolidated pyroclastic and } \\
\text { fluvio-lacustrine soils, surface water tables. }\end{array}$ & $\begin{array}{l}\text { Come down } \\
(0-0.25)\end{array}$ & $\begin{array}{c}\text { Marls, silts, sandstones } \\
\text { Sandy clay soils, } \\
\text { Marsh, fluvial-lacustrine, alluvial deposits }\end{array}$ \\
\hline
\end{tabular}


Table 6. Levels for the karstic influence considerations (Galbán \& Guardado, 2016).

\begin{tabular}{|c|c|c|c|c|}
\hline \multirow[b]{2}{*}{ Variable } & \multicolumn{4}{|c|}{ Evaluation grade } \\
\hline & $\begin{array}{c}\text { Low } \\
(0-0.25)\end{array}$ & $\begin{array}{l}\text { Moderate } \\
(0.26-0.5)\end{array}$ & $\begin{array}{c}\text { High } \\
(0.51-0.75)\end{array}$ & $\begin{array}{l}\text { Very high } \\
(0.76-1)\end{array}$ \\
\hline $\begin{array}{l}\text { Karstic } \\
\text { influence }\end{array}$ & $\begin{array}{l}\text { Karst discovered and } \\
\text { semi-discovered. } \\
\text { Collapses, falling blocks, formation } \\
\text { of casimbas, caverns, sinkholes, } \\
\text { sinkholes, etc., of large dimensions, } \\
\text { Development of typical endo } \\
\text { Karst and exo Karst such as mogotes, } \\
\text { dog's teeth, karst lagoons due to } \\
\text { the collapse of caves and erosion } \\
\text { of surface landforms. } \\
\text { Subsidence of large tracts of land, } \\
\text { well-developed karst areas. }\end{array}$ & $\begin{array}{l}\text { Karst covered by a layer thin soil, it } \\
\text { may also be assumed for areas with } \\
\text { imminent carsick development when } \\
\text { determining a high level of porosity } \\
\text { and permeability in sedimentary } \\
\text { formations. } \\
\text { Collapses, fall of blocks, formation of } \\
\text { casimbas, caverns, sinkholes, etc., of } \\
\text { considerable diameters, collapsed } \\
\text { cliffs, typical karst of active tectonic } \\
\text { zones with faulted or cracked areas } \\
\text { favoring the action of groundwater } \\
\text { in its degradation, etc. Differential } \\
\text { subsidence. Developed karst areas. }\end{array}$ & $\begin{array}{l}\text { Karst covered by potency } \\
\text { deposits when there } \\
\text { are very deep soils } \\
\text { (>1 m. and sometimes } \\
\text { more than } 10 \text { meters deep) } \\
\text { and that } \\
\text { They generally do not have } \\
\text { a direct genetic association } \\
\text { with limestones. } \\
\text { Moderate collapses, } \\
\text { formation of dog's teeth, } \\
\text { casimbas, caverns, etc., } \\
\text { of reduced diameter, etc. }\end{array}$ & $\begin{array}{l}\text { No karst, Scarce } \\
\text { development of } \\
\text { karstic forms, } \\
\text { they only } \\
\text { appear } \\
\text { in isolation, } \\
\text { very reduced endo } \\
\text { Karst forms. } \\
\text { Because it is } \\
\text { considered as } \\
\text { practically absent. }\end{array}$ \\
\hline
\end{tabular}

- Vegetation cover sub-model: With the appearance of intense rains, infiltration and runoff can vary depending on the vegetation cover, mainly in the hydroregulatory strips that correspond to the first flood plain. A forest cover will allow, in the event of intense rains or marine upwelling, a retarding hydroprotection action, including anti-erosion (Table 7).

- Submodel of the level of the water table: The water table generally coincides with the maximum average level reached in the water table or saturated zone, depends on the geological and climatic circumstances, and can be found at different depths, from only a few centimeters to several meters deep. These variations in the level of the water contained in the subsoil, is an extremely influential agent when it is close to the surface, causing saturation of the soils and therefore facilitating floods to occur more easily (Table 8).

For there to be floods, in addition to the susceptibility of the terrain or flood scenario, heavy rains must be present. To determine the trigger factor (intense rains), isoyetic maps of maximum rains in 24 hours are calculated for the different study regions and their standardization is verified as stated in Table 9.

If historical rainfall records are not available, isoyetic maps that express the historical mean of rainfall by region could be used. The greater the amount of annual rainfall that occurs in an area, the greater the possibility of favoring the occurrence of a flood (Table 10). Their values should be equally standardized.

In the specific case of marine upwelling floods, the following formulation is assumed:

$$
\mathrm{P}_{\text {ipm }}=\sum_{n=1}^{\infty} \mathrm{Ia} \text { (weight) } * \mathrm{Fds}(\text { weight })
$$

where:

- $\mathrm{P}_{\mathrm{ipm}}$-Primary model of upwelling flooding.

- Ia-Susceptibility indicators of the flood scenario (the same one described above) 
Table 7. Levels for plant cover considerations (Galbán \& Guardado, 2016).

\begin{tabular}{ccccc}
\hline & \multicolumn{4}{c}{ Evaluation grade } \\
\cline { 2 - 5 } Variable & Low & Moderate & High & Very high \\
$(0-0.25)$ & $(0.26-0.5)$ & $(0.51-0.75)$ & $(0.76-1)$ \\
\hline $\begin{array}{c}\text { Vegetable } \\
\text { cover }\end{array}$ & $\begin{array}{c}\text { Tree cover } \\
\text { (forests) }\end{array}$ & $\begin{array}{c}\text { Tree cover (forests) with } \\
\text { intercalations of fruit } \\
\text { crops and plantations }\end{array}$ & $\begin{array}{c}\text { Tree cover (forests). } \\
\text { herbaceous and shrub cover } \\
\text { (thickets and secondary } \\
\text { herbaceous communities) }\end{array}$ & $\begin{array}{c}\text { No } \\
\text { vegetation }\end{array}$ \\
\hline
\end{tabular}

Table 8. Categorization of the influence by depths of the phreatic levels (Galbán \& Guardado, 2016).

\begin{tabular}{ccccc}
\hline \multirow{2}{*}{ Variable } & \multicolumn{4}{c}{ Evaluation grade } \\
\cline { 2 - 5 } & Low & Moderate & High & Very high \\
$(0-0.25)$ & $(0.26-0.5)$ & $(0.51-0.75)$ & $(0.76-1)$ \\
\hline Water table (m) & Over 15 & $10-15$ & $3-10$ & $0-3$ \\
\hline
\end{tabular}

Table 9. Levels for the evaluation of the trigger factor.

\begin{tabular}{ccccc}
\hline \multirow{2}{*}{ Variable } & \multicolumn{4}{c}{ Evaluation grade } \\
\cline { 2 - 5 } & Low & Moderate & High & Very high \\
\hline $\begin{array}{l}\text { Trigger factor for } \\
\text { heavy rain }(\mathrm{mm})\end{array}$ & $\leq 100$ & $>100$ and $\leq 285$ & $>285$ and $\leq 490$ & $>490$ \\
\hline
\end{tabular}

Table 10. Levels for consideration of the annual rainfall. According to (Galbán et al., 2012).

\begin{tabular}{ccccc}
\hline \multirow{2}{*}{ Variable } & \multicolumn{4}{c}{ Evaluation grade } \\
\cline { 2 - 5 } & Low & Moderate & High & Very high \\
\hline \multirow{2}{*}{ Historical rainfall $(\mathrm{mm})$} & $\leq 600$ & 600 and $\leq 1700$ & 1700 and $\leq 2500$ & $\geq 2500$ \\
& $(0-0.25)$ & $(0.26-0.5)$ & $(0.51-0.75)$ & $(0.76-1)$ \\
\hline
\end{tabular}

- Fds-Trigger factor (surge).

- $n$-number of indicators.

- Weight-weight assigned to trigger factor and land scenario in correspondence of kind of hydro meteorological phenomena in analysis as stated above in Table 3. Always goes from $0-1$ (the sum of the weights must be equal to 1).

In this study are assumed indicators for the flood stages, which coincides with previously discussed, only changes the trigger factor in the formulation, which in this case is the marine upwelling that for different categories of hurricanes is assumed from the studies of NOAA, previously exposed (Table 11).

\section{Results}

For the application of the proposed methodology, the Seville sector was chosen. The study area is located in the southeastern region of the Republic of Cuba, in 
Table 11. Classification of the hazard generated by the hurricanes or tropical cyclones in terms of marine upwelling.

\begin{tabular}{ccc}
\hline Category & Storm Surge $(\mathrm{m})$ & Standardized values \\
\hline Category 1 & 1.5 & $>0.25$ \\
Category 2 & $2.0-2.5$ & $>0.25$ \\
Category 3 & $2.5-4.0$ & $(0.26-0.5)$ \\
Category 4 & $4.0-5.5$ & $(0.51-0.75)$ \\
Category 5 & $>5.5$ & $(0.76-1)$ \\
\hline
\end{tabular}

the province of Santiago de Cuba, Guamá municipality. To the south it limits with the Caribbean Sea; to the north, with the Contramaestre municipality and to the west with the Santiago de Cuba Municipality, having as a notable point the town of Bahía Larga, which has a single road that guarantees communication between it and the town of Chivirico, head of the municipality and the city of Santiago from Cuba. Towards the interior of the basin there are only embankments and local roads, in addition to other scattered settlements. The coastal sector is located from the town known as El Marañón to the town known as El Mazo, it extends along the coastline with a length of approximately $16.57 \mathrm{~km}$, covering a surface area of $94.4 \mathrm{~km}^{2}$ (Figure 5).

From the geological point of view, the rocks that exist attached to the coast are fundamentally carified or dolomitized biohermic limestone, with intercalations of conglomerates and sandstones. Behind these, inland, are represented tobaceous and basaltic igneous rocks belonging to formations of the El Cobre group in the Sierra Maestra. Mangrove swamps and coastal vegetation abound in the area. The forests occupy the highest surface, although their development is medium due to the scarce rainfall in the area. The rest of the territory is dedicated to raising animals, planting various crops on small scales, coffee and isolated buildings.

The coastal strip presents elevations that up to $10 \mathrm{~m}$ above mean sea level have slopes of $0^{\circ}$ up to $28^{\circ}$. The relief that surrounds this coastal strip is very rugged. There are several rivers, the most important is the Seville River, and there are also the rivers: El Ají, Tabacal, Magdalena and Jobo. All on the southern slope with characteristics of Mountain Rivers with intermittent flows, especially towards the coastal part (Figure 6).

During the investigation it is confirmed that, in Santiago de Cuba, coastal flooding is also conditioned by elements related to the scant extension of the continental shelf and coral reefs (Figure 7); as well as the existence of moderately compacted rocks of the sedimentary and volcanogenic sedimentary type that facilitate the erosive action of the waves on them, in addition to a scarce development of the coastal vegetation.

Technical consultation was carried out with specialists from various institutions and companies in order to obtain information and data on the study area. From these, the following were obtained: 


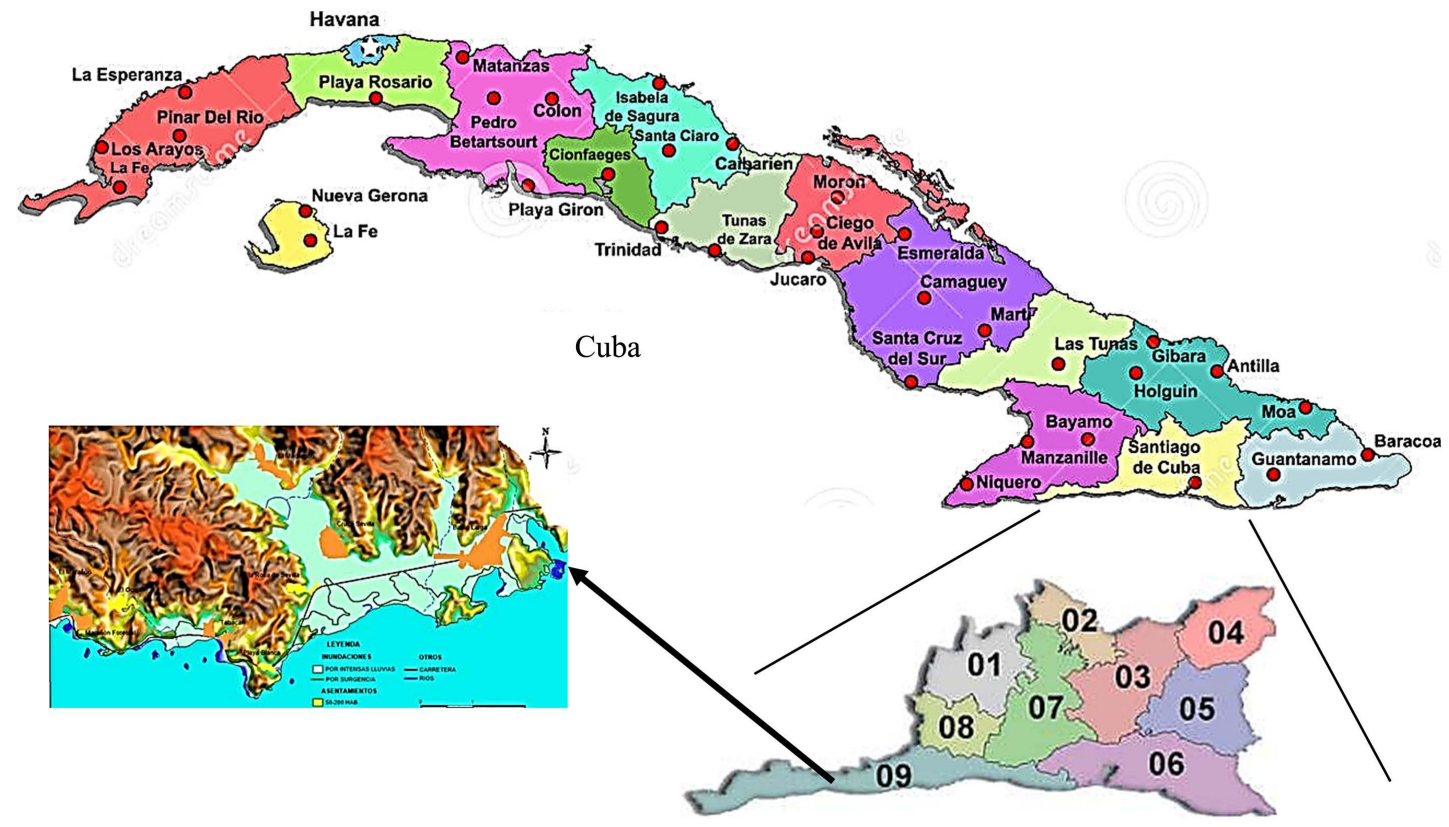

Figure 5. Location of the study area.
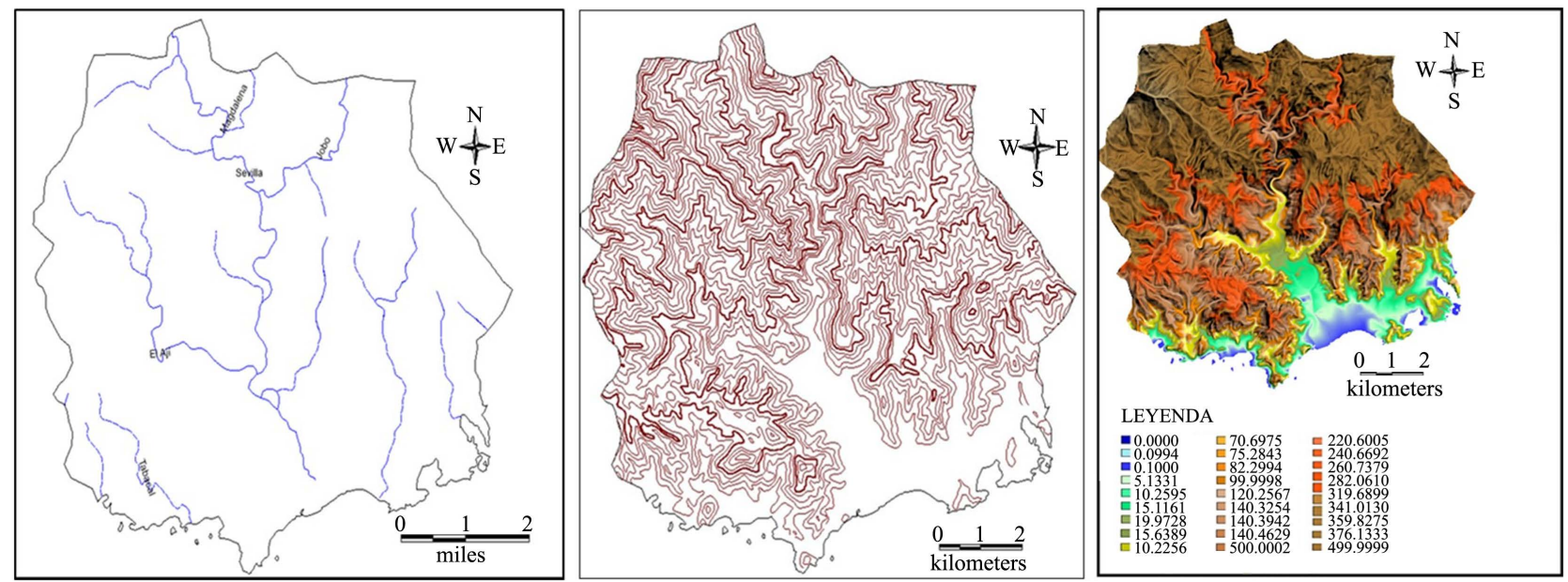

Figure 6. Coastal sector Seville in the Guamá municipality. From left to right: Hydrographic network, Bump map and Digital elevation model. Source: Geocuba Oriente Sur (2010).

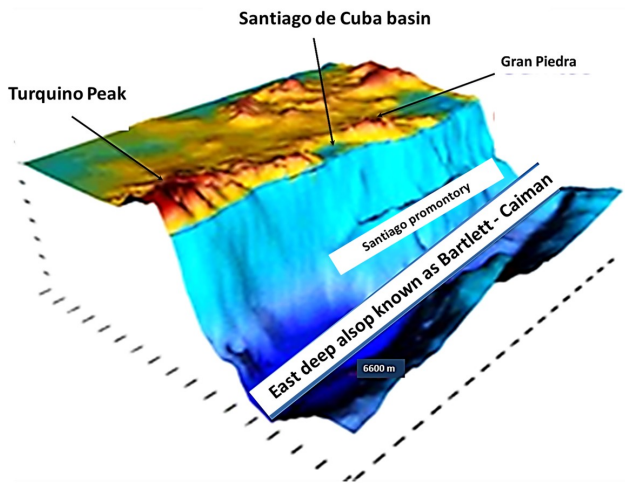

Figure 7. Digital model of the coastal area of Santiago de Cuba with bathymetric inclusion, where the scant extension of the continental shelf is observed (Álvarez et al., 2005). 
- Historical average annual rainfall model 1:10,000.

- 1:10,000 water table model.

- Vegetation model 1:10,000.

- 1:10,000 lithological susceptibility model.

- Karstic presence model.

In addition, it was possible to acquire other data necessary for the analyses such as:

- Limit of floods due to heavy rains, at a scale of 1:25,000, from studies carried out in 2016 by the PVR study group of the province.

- Limit of floods due to penetrations of the sea, at a scale of 1:25,000, from studies carried out in 2016 by the PVR study group of the province.

- Report of the PVR studies of floods due to heavy rains in the Santiago de Cuba municipality carried out in 2011 and 2016.

- Topographic map 1:10,000.

- Rain and cyclone data corresponding to the study area.

The cartographic base used for the research has been the 1:25,000 map of the Santiago de Cuba province obtained from the company Geocuba Oriente Sur (2010), from which the necessary thematic layers have been extracted for the interpretation of the map of hazard. Once this is done. The maps were reclassified as stated in the procedure. All indicators and weights were standardized in this way it was obtained for each indicator a standardized and reclassified submodel (Figures 8-11).

The previous formulations were then applied and the primary models of hazard due to river flooding (Figure 12) and hazard due to marine upwelling (Figure 13) were obtained.
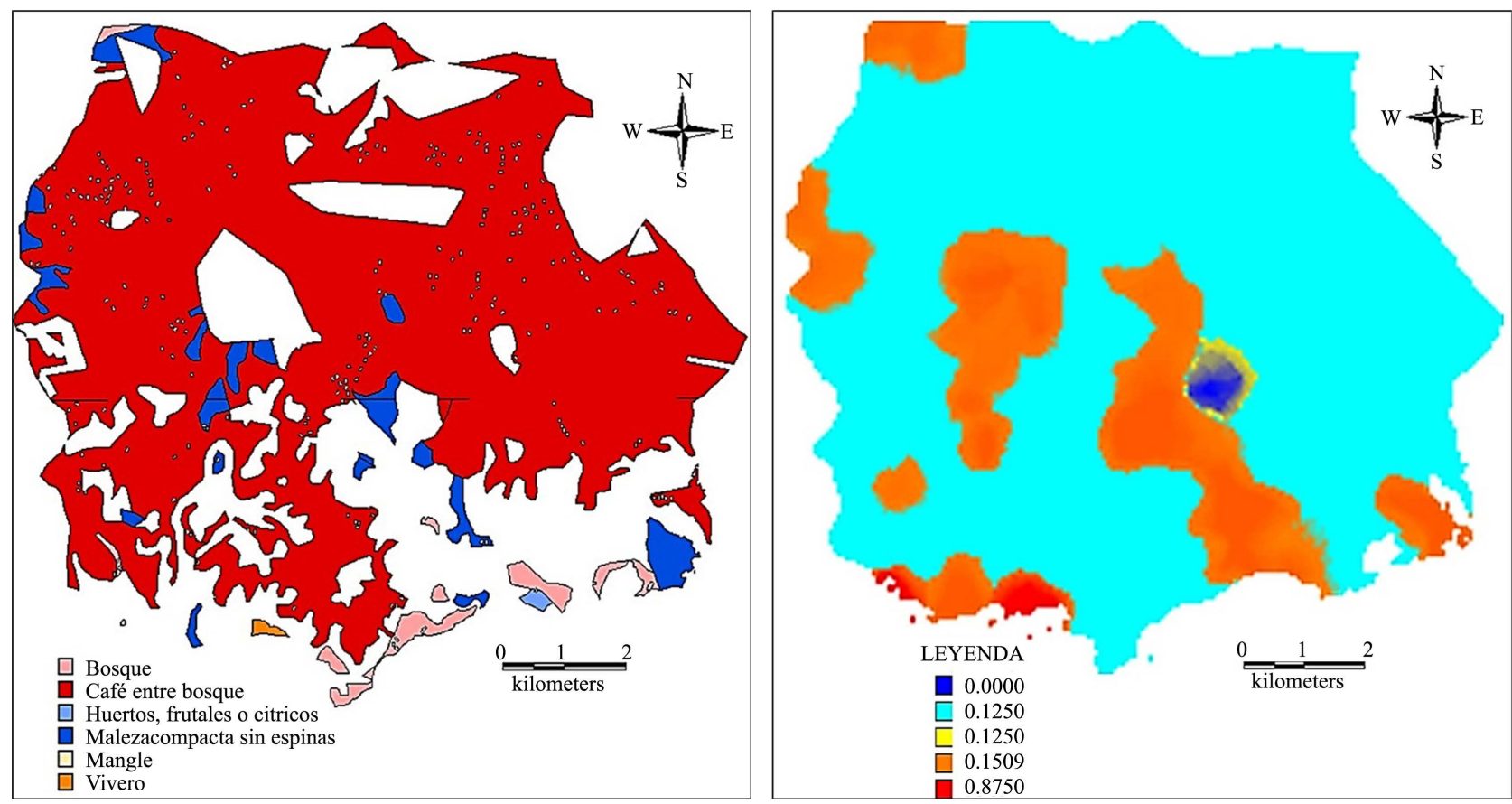

Figure 8. Representation of vector and raster vegetation maps of the Sevilla Sector, Guamá in Santiago de Cuba. 

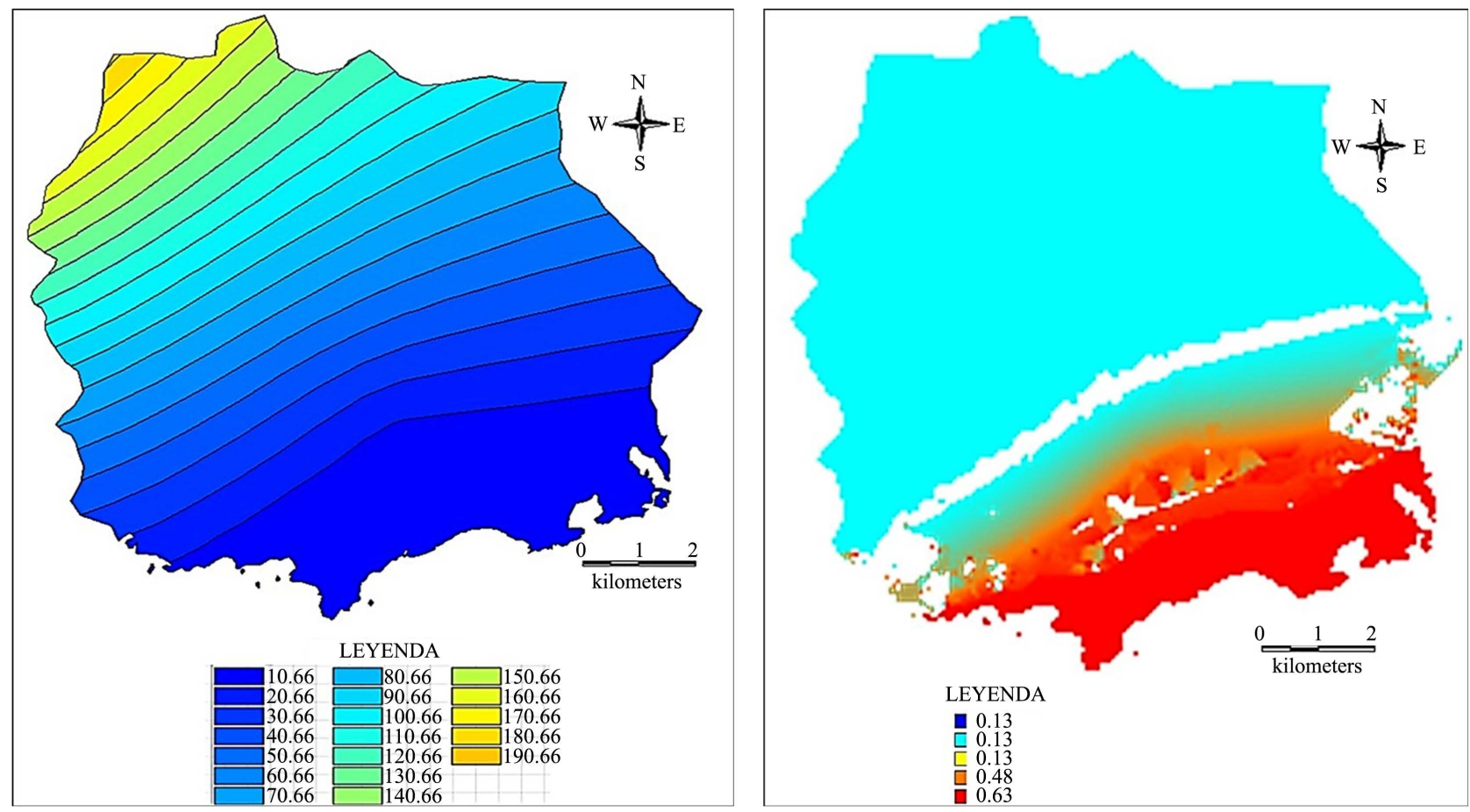

Figure 9. Representation of vector and raster maps of the phreatic levels of Sector Sevilla, Guamá in Santiago de Cuba.

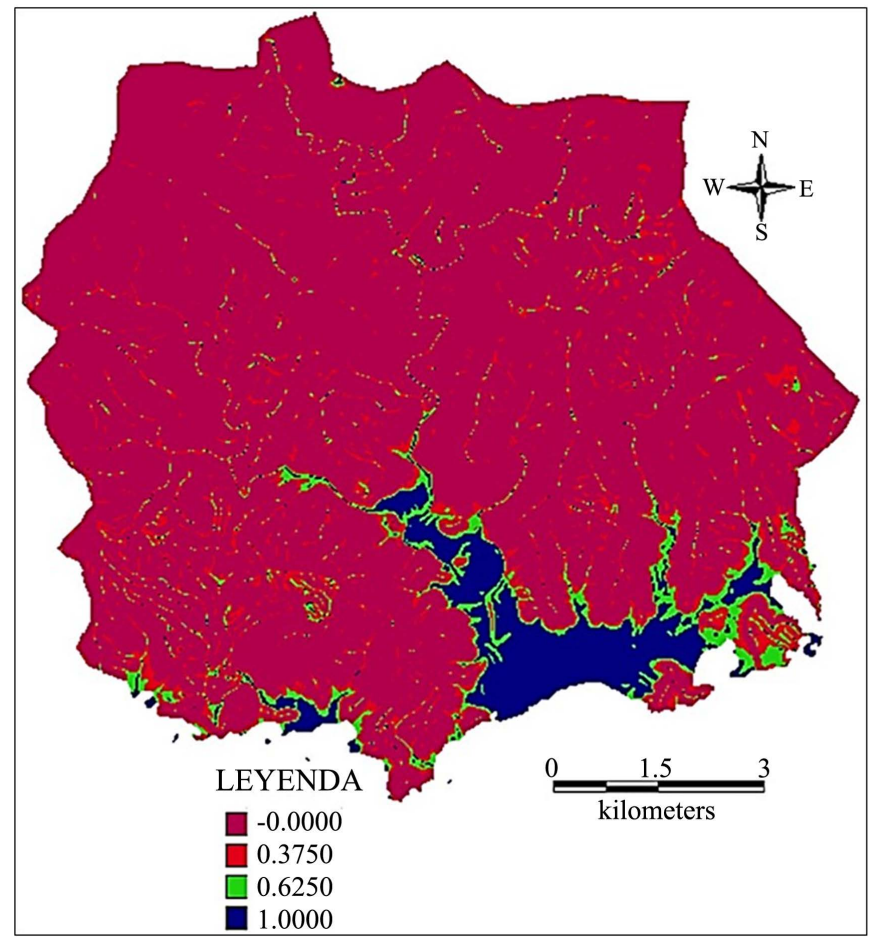

Figure 10. Representation of the slope raster map of Sector Sevilla, Guamá in Santiago de Cuba.

In order to obtain the areas at risk of coastal flooding due to the joint effect of the intense rains and the upwelling, the general formulation set forth was applied. The results are shown in Figure 14. 

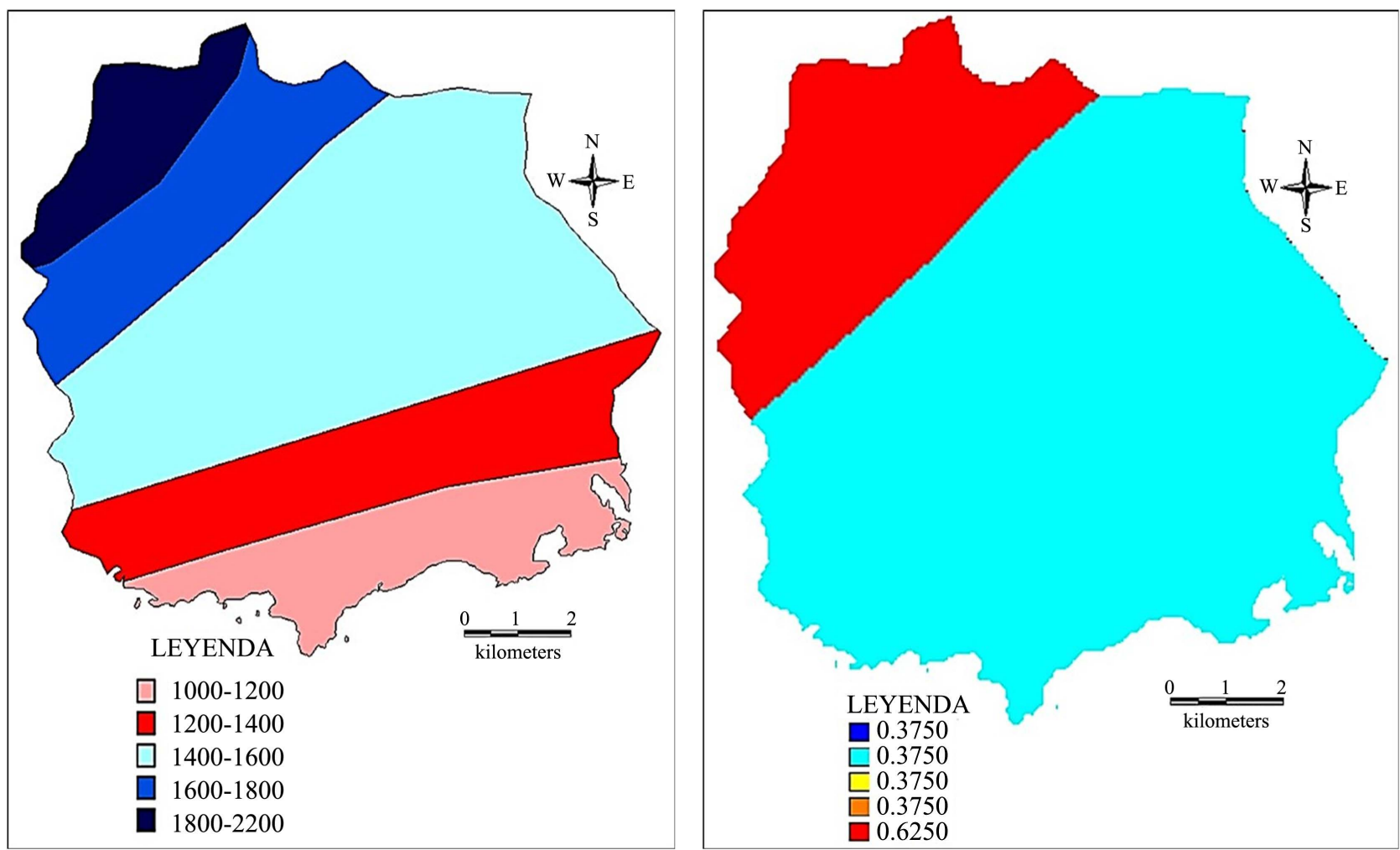

Figure 11. Representation of vector and raster precipitation maps of the Sevilla Sector, Guamá in Santiago de Cuba.

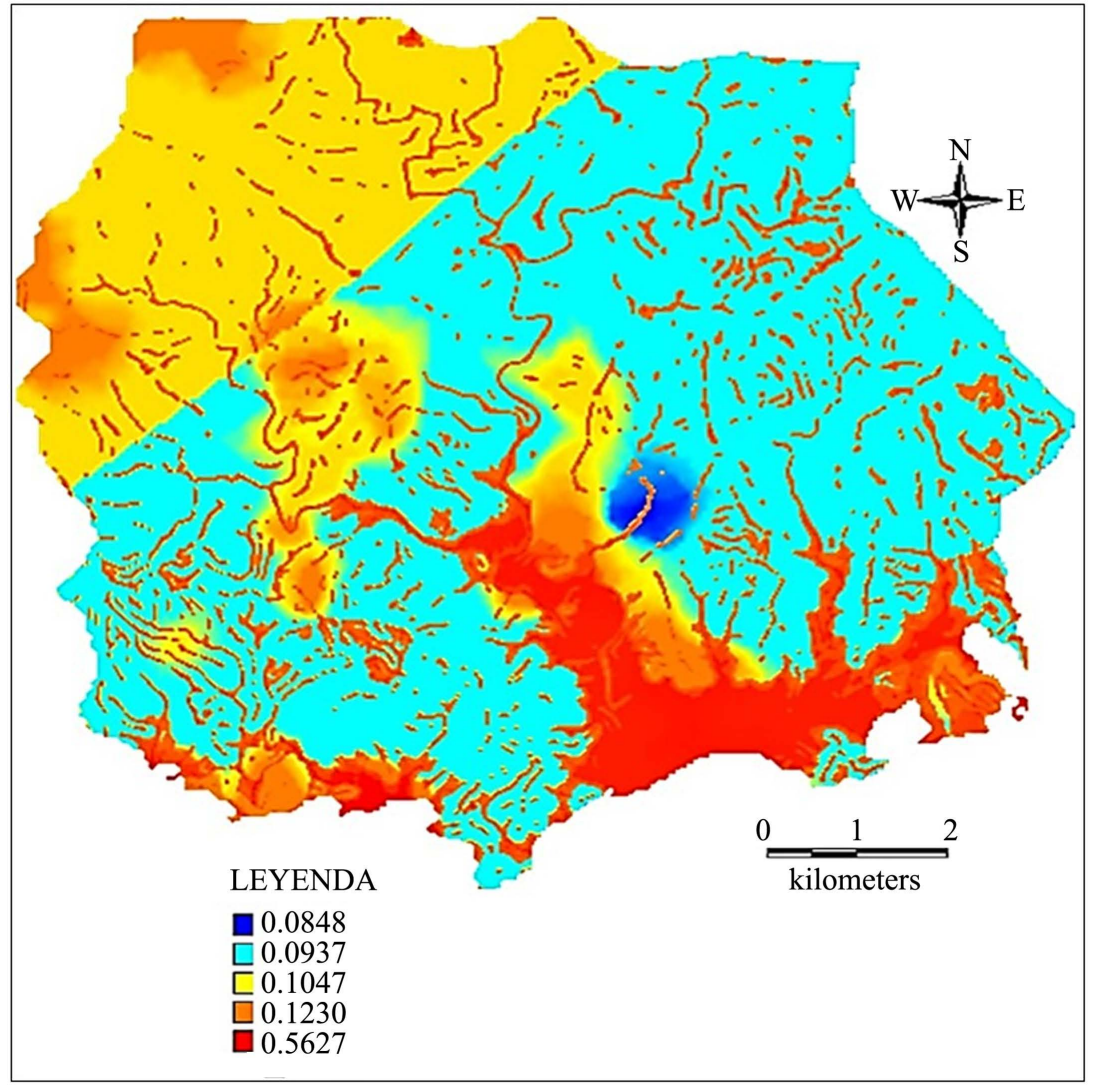

Figure 12. Reclassified primary model of flood hazard due to heavy rains. 

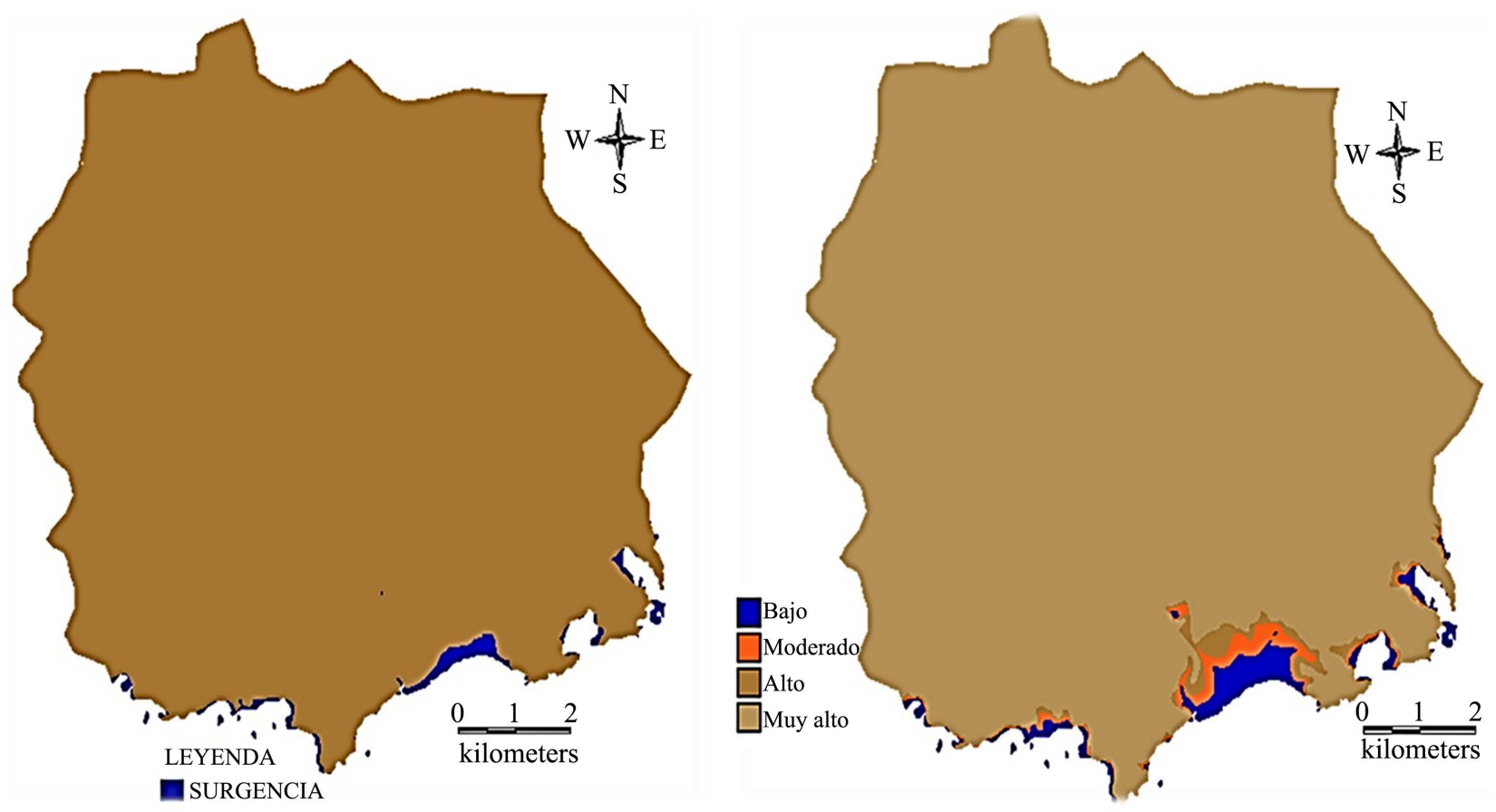

Figure 13. Models with the maximum levels that the upwelling reaches in the coastal sector Seville. On the left Hurricane category 1 and on the right up to category 5 .

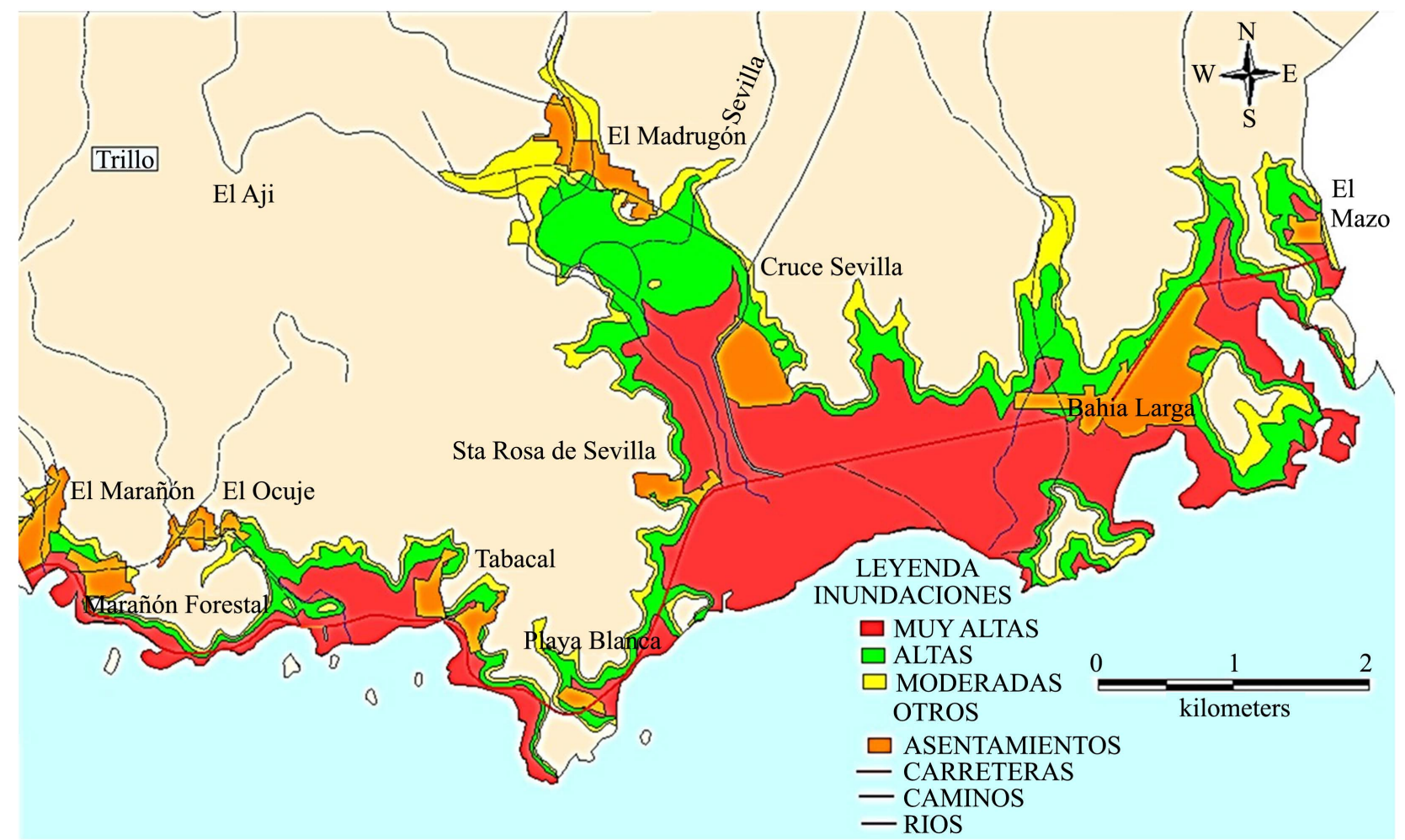

Figure 14. Map of total coastal floods of the Seville coastal sector.

\section{Discussion}

The author is of this work coincides $n$ to studies conducted by the group of PVR 
province to the state that coastal flooding due to the upwelling sea penetrations are recorded through the mouths of rivers. However, in other areas such as Santa Rosa, Cruce de Sevilla, El Madrugón, Bahía Larga and El Mazo, the flooding is produced due to the accumulation of water by the intense rains in the lower parts of the first levels of marine terraces and, the penetration of the sea by effect of the upwelling.

The area most affected is the Bahía Larga town where the sea could penetrate $1.97 \mathrm{~km}$ and affect service areas and stretches of roads that can interrupt communications with the population that lives further west of the town. A then a table is shown with main effects that happen when the two types of flooding agree and 1 space and time (Table 12).

The comparison of the studies carried out by the PVR group of the province and the authors of the present work show the following results.

The highest amounts of sea penetrations occur at the mouths of rivers and troughs and therefore the combination of the two types of floods occur in these sites, except in Santa Rosa, Cruce de Sevilla, El Madrugón, Bahía Larga and El Mazo.

The studies carried out by the PVR group of the province, in the study area, show 6 places of flooding and those carried out with the present work 10; that is, 4 more places are discovered: Marañón Forestal, El Ocuje, Playa Blanca and El Mazo.

The length of the floods and therefore the affected area is greater when floods due to intense rains and upwelling are combined, so the population and infrastructure affected is considerably greater than in the studies of the HVR group of the province.

Finally authors would like to recommend to international specialists to use regression model feting between the actual data and the prediction data make more accurate their studies when apply our propose procedure.

Table 12. Effects due to the occurrence of upwelling floods and heavy rains.

\begin{tabular}{|c|c|c|c|c|c|c|c|}
\hline Settlements & $\begin{array}{c}\text { Area full of } \\
\text { affectation }\left(\mathrm{Km}^{2}\right)\end{array}$ & $\begin{array}{l}\text { Penetration } \\
\text { length }(\mathrm{m})\end{array}$ & $\begin{array}{l}\text { Total } \\
\text { homes }\end{array}$ & $\begin{array}{l}\text { Affected } \\
\text { homes }\end{array}$ & $\begin{array}{c}\text { Affected } \\
\text { population }\end{array}$ & Facilities affected & $\begin{array}{l}\text { Road section } \\
\text { affected }(\mathrm{km})\end{array}$ \\
\hline El Marañón & & 790 & 179 & 154 & 105 & Installations of services & \\
\hline Marañón forestal & & 455 & 141 & 136 & 525 & Service facilities & \\
\hline El Ocuje & & 358 & 56 & 12 & 440 & Installations of services & \\
\hline Tabacal & & 493 & 76 & 70 & 167 & Installations of services & \\
\hline Playa Blanca & & 372 & 32 & 32 & 224 & Installations of services & \\
\hline Sta. Rosa de Sevilla & 12.3 & 438 & 28 & eleven & 212 & Installations of services & 12 \\
\hline El Madrugón & & 876 & 63 & 48 & 68 & Installations of services & \\
\hline Cruce de Sevilla & & 713 & 85 & 85 & 202 & Service facilities & \\
\hline Bahía Larga & & 666 & 213 & 213 & 675 & Installations of services & \\
\hline El Mazo & & 312 & 139 & 139 & 377 & Installations of services & \\
\hline Total & & 5473 & 1012 & 900 & 2995 & & \\
\hline
\end{tabular}

Note: The data on dwellings, population, etc., were provided by the Municipal Directorate of Physical Planning in the Santiago de Cuba municipality. 


\section{Conclusion}

- The studies of total coastal flooding during the occurrence of extreme hydro meteorological phenomena in Cuba and internationally, has shown deficiencies in the combination of river flooding and marine upwelling, doe to the lack of a formulation that introduces the rising of the water level experimented when both flooding interact in the coastal zone.

- A procedure designed by the authors to determine the hazard of total coastal flooding during the impact of hurricanes is explained, which uses in its formulation the density factor of the water that finds an explanation for the effect of shielding and rising of the water level when the currents of both floods collide in the coastal zone.

- The application of the proposed procedure experimentally in the coastal sector Sevilla, of the municipality Guamá in Santiago de Cuba province, resulting in the confirmation of areas previously estimated; in addition to other new areas that confirm the actual visual and instrumental observations not included in previous studies of coastal flood hazard in this area.

\section{Acknowledgements}

The assessments made in this work correspond to the first phase of the project "monitoring and integrated management of coastal ecosystems facing climate change in the eastern region of Cuba. (ECOS)". 2021-2025. Sectorial Program "higher education and sustainable development". Cuba.

\section{Conflicts of Interest}

The authors declare no conflicts of interest regarding the publication of this paper.

\section{References}

Álvarez, G. J., Peláez, J. G., et al. (2005). New Generation of Estimates of Seismic Hazard with the Associated Error for Cuba and Calculation of Losses for the City of Santiago de Cuba Using GIS Techniques. Archives of the National Center for Seismological Research.

AMA (2014). Methodologies for Determining Disaster Risks at the Territorial Level. Havana, Cuba, Manual Edited by the National Office for Risk and Disaster Program. https://docplayer.es/storage/19/221092/221092.pdf

Blake, E. S., Landsea, C. W., Gibney, E. J., National Climatic Data Center, \& National Hurricane Center (2011). The Deadliest, Costliest and Most Intense United States Tropical Cyclones from 1851 to 2010 (and Other Frequently Requested Hurricane Facts). NOAA Technical Memorandum NWS NHC-6 (National Oceanic and Atmospheric Administration). p. 47.

https://www.researchgate.net/publication/237806994_The_Deadliest_Costliest_and_M ost_Intense_United_States_Tropical_Cyclones_From_1851_to_2006_and_Other_Freq uently_Requested_Hurricane_Facts

Brakenridge, R. G. (2016). Global Active Archive of Large Flood Events. Dartmouth Flood Observatory, University of Colorado, USA. 
http://floodobservatory.colorado.edu/Archives

Galbán, R. L. (2014). Procedure for the Management and Reduction of Geological Risks in the Santiago de Cuba Province. PhD Thesis in Geological Sciences, Higher Institute of Metallurgical Mining, Moa, Holguín, Cuba.

Galbán, R. L., \& Guarded, L. R. (2016). Modeling of the Hazard of Landslides in the Municipality of Santiago de Cuba Considering the Weight of the Determining Variables. Magazine of the Argentine Museum of Natural Sciences, 18. https://www.researchgate.net/publication/315441686_Modeling_of_landslide_hazard_i n_the_Santiago_de_Cuba_Municipality_considering_the_weight_of_the_determinant variables

Galbán, R. L., Quintana, I. N. V., et al. (2012). Indicadores más comunes en la evaluación de riesgos geológicos. Indicadores cualitativos y cuantitativos para la evaluación de peligro, vulnerabilidad y riesgos geológicos. A. Española. Editorial Académica Española (July 6, 2012)Madrid. España.

https://www.amazon.com/Indicadores-comunes-evaluaci\%C3\%B3n-riesgos-geol\%C3\% B3gicos/dp/3659028495

Geocuba, O. S. (2010). Digital Database of Cartographic Data of the Province of Santiago de Cuba at a Scale of 1:100 000. Courtesy of the Authors.

Lara, S. M. A. (2012). Social Perception in Flood Risk Management in a Mediterranean Area (Costa Brava, Spain). Doctoral Thesis, Girona: Girona University. http://hdl.handle.net/10803/98249

Luu, C., Meding, J. V., \& Kanjanabootra, S. (2017) Assessing Flood Hazard Using Flood Marks and Analytichierarchy Process Approach: A Case Study for the 2013 Flood Event in Quang Nam, Vietnam. Nat Hazards, Springer.

https://www.researchgate.net/publication/320757449_Assessing_flood_hazard_using_fl ood_marks_and_analytic_hierarchy_process_approach_a_case_study_for_the_2013_fl ood_event_in_Quang_Nam_Vietnam

Rodriguez, L. G. (2020) Inundaciones. Desafío de la naturaleza.RakutenKobo Inc. Publishing Services. Toronto, Ontario, Canadá.

https://www.kobo.com/ww/es/ebook/inundaciones-desafio-de-la-naturaleza

Tellman, B., Sullivan, J. A., Kuhn, C., Kettner, A. J., Doyle, C. S., Brakenridge, G. R., Erickson, T. A., \& Slayback, D. A. (2021). Satellite Imaging Reveals Increased Proportion of Population Exposed to Floods. Nature, 596, 80-86.

https://doi.org/10.1038/s41586-021-03695-w

https://www.nature.com/articles/s41586-021-03695-w 